\title{
An Analysis on the Development Status and Innovation Path of Cross-Border E-Commerce in Yunnan Under the Background of Lancang- Mekong River Cooperation
}

\author{
Xiaobo Gao \\ International Business School \\ Yunnan University of Finance and \\ Economics \\ Kunming, China \\ 275499677@qq.com
}

\author{
Hong Yi* \\ International Business School \\ Yunnan University of Finance and \\ Economics \\ Kunming, China \\ ynyihong@126.com
}

\author{
Li Guo \\ International Business School \\ Yunnan University of Finance and \\ Economics \\ Kunming, China \\ 1024181289@qq.com
}

\begin{abstract}
Under the Lancang-Mekong river cooperation mechanism, the development of cross-border e-commerce in Yunnan has brought unprecedented opportunities. The development of cross-border e-commerce is also one of the most important forms of implementing the "One Belt And One Road" initiative. At present, there are many problems in the development of cross-border e-commerce between Yunnan and the five Lancang-Mekong countries. Combining the status quo of cross-border e-commerce development in Yunnan, The study believes that the establishment of a cross-border e-commerce customs clearance system in the region, the establishment of a cross-border e-commerce logistics system in the region, the construction of a cross-border e-commerce cooperation park in the region, the construction of a cross-border e-commerce talent training base in the region, and the strengthening of cross-border The promotion and promotion of e-commerce is a factor that promotes the innovative development of cross-border ecommerce in Yunnan.
\end{abstract}

Keywords: Lancang-Mekong river cooperation, Yunnan crossborder e-commerce, innovation path

\section{INTRODUCTION}

Since the launch of the "Belt and Road Initiative" initiative, it has received positive responses from many countries and regions in the world. At present, China and the countries and regions along the "Belt and Road" have achieved good cooperation in policy communication and smooth trade. The five Mekong countries are China. The important areas along the "Belt and Road Initiative" have become one of the most promising regions in Asia and the world. In recent years, with the strong economic growth of the country, the trade status in the world economy has gradually increased and become the highlight of the world economy. The increasingly frequent trade between China and the country is conducive to promoting the economy and cooperation of the five countries. With the popularity of the Internet and the updating of technical means, cross-border e-commerce as a new type of cross-border trade is actively promoting the cooperation and development of trade between China and the five countries. Cross-border ecommerce in the region has provided favorable guarantee for the construction of the China-ASEAN Free Trade Area and the construction of the "Belt and Road".

\section{AnAlysis OF the Status QuO OF CROSS-BORDER E- COMMERCE DEVELOPMENT}

\section{A. The scale of foreign trade in yunnan province is increasing year by year}

Since the launch of the Belt and Road Initiative, Yunnan's foreign trade development has brought new opportunities. The total value of Yunnan's foreign trade imports and exports has shown steady growth. According to relevant statistics, the import and export of Yunnan Province in 1918 was 193.7 billion yuan, an increase of $24.7 \%$ compared with 2017 . Of this total, exports were 84.77 billion yuan, up $9.4 \%$; imports were 112.53 billion yuan, up $39.3 \%$. The volume of import and export trade reached a record high, the export growth was stable, and imports grew rapidly. The overall foreign trade maintained a high growth level, which was 15 percentage points higher than the national foreign trade growth rate. From the perspective of foreign trade, the proportion of general trade in the province has increased from $57.9 \%$ in 2017 to $65.2 \%$; border trade has flourished, and the import and export of border residents has increased by $20.9 \%$. From the perspective of the foreign trade market, ASEAN accounted for $46.1 \%$ of the province's total import and export volume, of which the five countries became the largest trading economy, and its trade amount is shown in Figure 1. From the perspective of commodity structure, agricultural products, mechanical and electrical products Chemical fertilizers and labor-intensive products are the main commodities exported by Yunnan, while crude oil and natural gas are the main imported commodities, of which crude oil imports exceeded 10 million tons, reaching 10.16 million tons, accounting for $32.2 \%$ of the province's imports. 


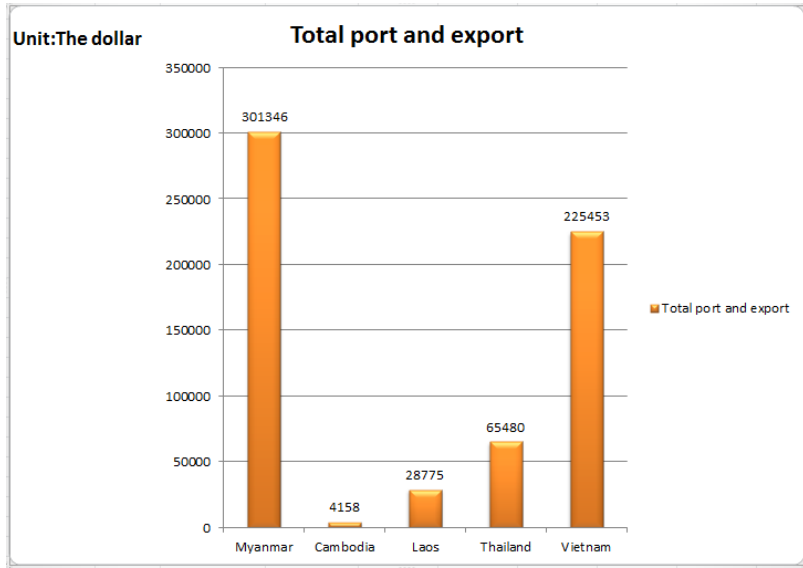

Fig. 1. In 2018, Yunnan's total import and export volume to the five Lancang-Mekong countries

\section{B. Cross-border e-commerce in Yunnan-Lancang-Mekong region is increasingly close}

In recent years, relying on location advantages and policies, Yunnan has actively promoted cross-border e-commerce construction and achieved great results, becoming an important node for cross-border e-commerce in Southeast Asia and South Asia. In July 2019, the State Council executive meeting decided to establish a new cross-border e-commerce comprehensive test zone in 22 cities including Kunming, which brought new opportunities for cross-border e-commerce in Yunnan. Yunnan Province completed the "single window" of China (Yunnan) international trade and the construction of a cross-border e-commerce public service platform in Yunnan Province. It established a cross-border e-commerce park in Yunnan Province at Changshui Airport and built a cross-border e-commerce display experience center. Integrated service center and supervision center. In May 2019, the direct purchase supervision center of Yunnan cross-border e-commerce park was put into trial operation.

With the advantages of Yunnan location and industry, Kunming City and Cambodia, Myanmar, Laos, Vietnam, and Thailand have jointly established the GMS cross-border ecommerce cooperation platform enterprise alliance to Kunming and operate. At the same time, as a market entity, enterprises are strengthening mutual cooperation, and they are exploring the Southeast Asian South Asian market. They are based on the GMS cross-border e-commerce trading platform and GMS cross-border e-commerce training platform and GMS. The cross-border e-commerce virtual incubator platform has been put on the shelves, and different versions of text can be generated through the translation system, which is more targeted to consumers in different countries.

At present, the development of cross-border e-commerce in Yunnan has shown a vigorous trend. According to statistics, in 2016, China's cross-border e-commerce has entered the "trillion era", and cross-border import e-commerce transactions reached 1.200 billion yuan. Looking at the domestic, Shenzhen, Hangzhou and other places, their cross-border e-commerce transactions have reached the level of "100 billion" and "tens billion". In contrast, there is still a big gap in Yunnan and it has huge potential for development.

\section{The cross-border e-commerce cooperation mechanism between Yunnan and Lancang-Mekong River countries is gradually improved}

Since the Lancang-Mekong river cooperation in 2016, it has greatly promoted bilateral economic cooperation and promoted the rapid development of the two economies. At the same time, since LMC, a series of relevant agreements and mechanisms on cross-border e-commerce cooperation between China and Lancang-Mekong countries have been continuously improved. In May 2017, China and Vietnam signed the memorandum of understanding on e-commerce cooperation, establishing a sound mechanism for e-commerce exchange and cooperation. In November of the same year, China signed with Cambodia the memorandum of understanding on e-commerce cooperation between the Ministry of Commerce of China and the Ministry of Commerce of Cambodia, which promoted exchanges and cooperation between China and Cambodia in such areas as policy communication, enterprise cooperation, joint research and personnel training.

On November 12, 2018, the countries of the Association of Southeast Asian Nations signed the ASEAN e-commerce agreement in Singapore, which greatly promoted the development of cross-border e-commerce trade in the region, and created a mutual trust environment for the application of ecommerce. The application of e-commerce further promotes regional economic growth and deepens cooperation among countries.

\section{OPPORTUNITIES BROUGHT ABOUT BY THE DEVELOPMENT OF CROSS-BORDER E-COMMERCE IN YUNNAN UNDER THE BACKGROUND OF COOPERATION}

\section{A. Economic cooperation among Lancang-Mekong countries has yielded results}

Since the establishment of the Lancang-Mekong river mechanism, China and the Mekong Five have adhered to the principle of "co-industry, co-construction and sharing" and pragmatically promoted cooperation in the field of cross-border economic cooperation in accordance with the $3+5$ cooperation framework. Significant results have been achieved in cooperation, facility connectivity, financial communication, and human communication. In the field of trade and intercommunication, China's trade with the five Mekong countries is developing rapidly and healthily. China has become the largest trading partner of Cambodia, Myanmar, Thailand and Vietnam. Laos' second largest trading partner, Vietnam has become China's largest trade in ASEAN. Partners; In the field of investment cooperation, since the signing of the "Joint Statement on National Capacity Cooperation", China and the Mekong River have achieved remarkable results in cooperation in the fields of power, power grid and automobile. In the field of facility connectivity, since the establishment of the cooperation mechanism, infrastructure interconnection between countries in the region has made significant progress, and infrastructure construction such as roads, power stations, shipping, and telecommunications among countries in the 
region has also been greatly developed. In the field of finance and finance, during the first leadership meeting of the Ministry of Cooperation, China announced that the 10 billion Yuan preferential loan to the Mekong region has been basically completed, playing a positive role in promoting economic and social development of all countries. In the field of humanities communication, tourism, health, culture, poverty alleviation and other areas of cooperation in the field of people's livelihood have been further promoted, and projects involving people's participation and benefit have been implemented smoothly. The establishment of the cooperation mechanism has promoted the development of cross-border e-commerce among countries.

\section{B. Establishment of china-asean free trade area}

With the establishment of china-asean free trade area, trade between China and asean countries has become free and trade between China and asean countries has become increasingly frequent. In 2018, China's import and export to asean increased by 11.2 percent. With this momentum of development, crossborder e-commerce between China and asean also grew rapidly. According to the research report on China's cross-border ecommerce market in 2018-2019, China's cross-border ecommerce transaction scale reached 9.1 trillion yuan in 2018, among which the export cross-border e-commerce transaction scale was 7.9 trillion yuan, up $25.4 \%$ year-on-year. The major countries of China's cross-border e-commerce export are the United States, the European Union and asean. Asean has been China's third largest trading partner for seven consecutive years and the third largest cross-border e-commerce export market for China. In 2018, Yunnan's import and export to asean accounted for 15.5 percent of the total import and export volume. It can be seen that Yunnan has a larger space to expand the layout and development of asean cross-border ecommerce market.

\section{Dehong - ruili china-myanmar cross-border e-commerce industrial park}

Ruili has an important window and channel role in geographical location, connecting China and Myanmar, facing Southeast Asia and connecting to South Asia. In the implementation of the "Belt and Road Initiative", it has an irreplaceable location advantage and plays an important role in stimulating South Asian and Southeast Asian countries to participate in cross-border e-commerce. The Ruili Municipal Government attaches great importance to cross-border ecommerce, and selects "Ruili Datong Industrial Co., Ltd." to undertake the construction of the China-Myanmar cross-border e-commerce industrial park. With the steady advancement of the China-Myanmar land and water transport project and the acceleration of the construction of the Dali Railway, Ruili has become increasingly mature in terms of transportation and logistics conditions in the cross-border e-commerce circulation, which has brought good opportunities for the development of cross-border e-commerce in Yunnan Province.

\section{PROBLEMS FACED BY CROSS-BORDER E-COMMERCE IN YUNNAN IN THE CONTEXT OF LANCANG-MEKONG RIVER COOPERATION}

\section{A. The customs clearance system for cross-border e- commerce in the lancang-mekong region is not sound}

The national customs clearance system is not perfect in Lancang-Mekong River, the institutional costs of import and export are high, and the cross-border inspection and quarantine and customs clearance procedures are complicated. Crossborder e-commerce is a small-value transaction, highfrequency import and export, and needs to go through customs clearance procedures quickly. However, the rapid advancement of small-scale trade is affected by the long-term efficiency and high cost of customs clearance.

\section{B. The logistics system of cross-border e-commerce in the Lancang-Mekong region is not perfect}

The logistics system of the Lancang-Mekong River countries is not perfect. In terms of the hardware of the logistics infrastructure, the infrastructure development of ports, highways and railways in various countries is uneven. The more developed countries in Thailand are relatively complete and the hardware facilities are advanced, while the other four less developed countries are the opposite. The logistics speed is not matched, the customs clearance is not coordinated, and the transportation cycle is long. These factors lead to low efficiency and high cost of the overall cross-border logistics, which has caused many SMEs to get into trouble. As far as software in the logistics infrastructure is concerned, the electronic data and electronic information platform connected by each country and local customs is insufficient, and the national informatization level is not high enough to handle logistics affairs through modern means, which also affects the efficiency of border logistics. At the same time, it is difficult to provide accurate positioning of goods in transit.

\section{Lack of cross-border e-commerce cooperation parks in lancang-mekong region}

The whole ecosystem of cross-border e-commerce industry chain in lancang-mekong region has not yet been formed. In the future, the competition of cross-border e-commerce is not the competition between single platforms, but the competition among the ecological circle of cross-border e-commerce. Cross-border electricity business ecosystem including the whole industry chain, manufacturing, trade, shipping, payment, logistics, customs clearance, settlement, foreign exchange settlement, involving trading main body includes: cross-border e-commerce platform, customers, suppliers, brands, manufacturers, service providers, need to optimize the integration of e-government services such as customs, taxation, foreign exchange, business resources, effective linkage, cooperative development, and large-scale mae countries without such e-commerce cooperation zone, so that hinder the development of rings mai all cross-border electricity companies. 


\section{The shortage of cross-border electricity merchants in Lancang-Mekong region}

Cross-border e-commerce is very scarce for cross-border ecommerce in countries in the region. Cross-border e-commerce involves professionals in foreign trade, logistics, e-commerce, finance, marketing, language, etc., as well as complex management and technology. Because cross-border ecommerce industry knowledge and technology update is fast, and the education level of countries is relatively backward, excellent cross-border e-commerce merchants are extremely lacking in countries.

\section{E. The avocacy and promotion of cross-border e-commerce is not enough}

The promotion and publicity of cross-border e-commerce are not enough, and the major networks and media are not well utilized to promote and publicize cross-border e-commerce, which leads to the government and enterprises' insufficient understanding of cross-border e-commerce policies and the insufficient participation of the government and major enterprises.

\section{INNOVATIVE WAYS TO PROMOTE THE DEVELOPMENT OF CROSS-BORDER E-COMMERCE IN YUNNAN PROVINCE}

\section{A. Establish a cross-border e-commerce customs clearance system in the lancang-mekong region}

Set up including online payment, fast customs clearance, inspection, tax rebates, logistics information tracking, credit certification and product safety recourse comprehensive service system of cross-border trade platform, based on the electronic customs clearance port, integration, development and largescale mae regional national regulators interconnectivity of egovernment and e-commerce site, make various cross-border business is dealt with, declare and electronically operation regulation for rings mae regional countries to facilitate crossborder e-commerce enterprises.

\section{B. Establish a cross-border e-commerce logistics system in the lancang-mekong region}

Establish a cross-border e-commerce logistics distribution system for countries in the lancang-mekong region based on their logistics development status and development plans, and use modern information technology to improve the service efficiency of logistics distribution in terms of inventory management, logistics information collection, transportation tracking and inquiry, etc. Improve the construction of existing logistics and distribution infrastructure, and promote the construction of overseas warehouses and border warehouses in the lancang-mekong region; We will build a number of demonstration and driving logistics projects in countries or regions where conditions permit, laying the logistics foundation for cross-border e-commerce.

\section{Building cross-border e-commerce cooperation parks in the lancang-mekong region}

Establish cross-border e-commerce cooperation parks in countries in the Lancang-Mekong region to provide a series of supporting services for cross-border e-commerce activities. Cooperation zone according to the requirements of the clustering, industrialization and internationalization, set up the import and export goods distribution center, warehousing, cargo, freight logistics, customs supervision and inspection center, office, living area, such as area, cultivation and the introduction of a group of outstanding cross-border ecommerce enterprises and talents, to cooperate to complete the import and export goods customs declaration, customs clearance, customs clearance, settlement, in the park for crossborder choose goods, payment, operations, logistics, financing, training, translation and other one-stop service, form a closedloop cross-border e-commerce ecological circle and the whole industrial chain.

\section{We will build training bases for cross-border e-commerce talents in the lancang-mekong region}

Build a Lancang-Mekong region cross-border e-commerce talent training base, train e-commerce professionals for countries in the Lancang-Mekong region every year, and train international senior talents in e-commerce and business big data for countries in the Lancang-Mekong region every year. We will build a multilingual e-commerce Internet training platform in the Lancang-Mekong region, and train online talents in e-commerce and cross-border e-commerce for countries in the Lancang-Mekong region every year. We will build an Internet platform for international talent employment services in e-commerce in the Lancang-Mekong region, and provide cross-border talent services for countries in the Lancang-Mekong region.

\section{E. Strengthen the publicity and promotion of cross-border e- commerce}

We will strengthen the publicity and promotion of crossborder e-commerce cooperation, use various media and magazines to expand the publicity coverage, and help enterprises and governments better understand the policies and progress of cross-border e-commerce promotion in the lancang-mekong region. Actively guide enterprises to carry out cross-border e-commerce business and promote the vigorous development of cross-border e-commerce cooperation in the region. The government takes the lead to hold cross-border ecommerce summit, build a platform for enterprises to carry out cross-border e-commerce services, hold various trainings and lectures, publicize various promotion policies and practical operations, and improve the business application level of enterprises.

\section{SUMMARY}

In general, cross-border e-commerce in Yunnan Province still has problems such as imperfect customs clearance system, imperfect logistics system, shortage of multi-language cross-border e-commerce platform, shortag 
of multi-language cross-border e-commerce platform, shortage of cross-border electricity merchants, and insufficient cross-border e-commerce propaganda. However, under the "One Belt, One Road" and cooperation mechanism, Yunnan Province is also making efforts to promote the development of cross-border e-commerce in Yunnan, and to play a role as a radiation center for the Southeast Asian market in South Asia. At present, cross-border e-commerce in Yunnan Province already has a certain foundation, and has also established its unique cross-border e-commerce platform, but the road to expand overseas markets has a long way to go. Therefore, it is necessary to face up to its current situation and problems, use its location advantages and national cultural characteristics, and continuously optimize the development environment of cross-border e-commerce, so that Yunnan Province has a vast international market and great potential for developing cross-border e-commerce.

\section{ACKNOWLEDGMENT}

We would like to extend our deep gratitude to all those who have offered us practical, cordial and selfless support in writing this thesis, especially our teacher Professor Shake Feng and Hong Yi who help us with dedicated heart.

\section{REFERENCES}

[1] Hanyue Zhang, "Research on the development path and countermeasures of cross-border e-commerce in Yunnan province from the perspective of "One Belt And One Road" [J] ". China market, 2018(9), pp183-186.

[2] Xuesong Zhao and Tianyang Zhang, "Analysis on the development problems and countermeasures of cross-border e-commerce in Yunnan province [J]. " E-commerce, 2018(3), pp19-25.

[3] Xia Lee and Qi Ke, "Research on strategies of china-Asean cross-border e-commerce development under the background of "One Belt And One Road" [J]." Foreign economic and trade practice, 2019(9), pp33-36.

[4] Yang Qiao, Hongjuan Ma, JiaMing Li and Xuemei Wu, "Development status and innovation path of cross-border e-commerce in Heilongjiang province under the background of "One Belt And One Road" [J]." Economist, 2019(8), pp8-10

[5] Huan Luo and Fanping Kong, "Research on countermeasures for the development of cross-border e-commerce in Yunnan [J]." Technology and market, 2019 (5), pp181-182

[6] Yingbo Liu, "Research and development of cross-border e-commerce in Yunnan under the strategy of "bridgehead" [J]." China commerce and trade, 2015 (6), pp40-42 